\section{Energy hit}

\section{Germany's decision to slow the expansion of} green-energy production is a reasonable move.

$\mathrm{F}$ or a few hours around lunchtime on a bright and windy day last month, Germany paid people to use electricity. The country's investment in renewable energy has paid off so handsomely that green power sources produced almost enough electricity to meet national demand. Because the rest of the energy infrastructure - nuclear, coal and gas stations - was online too, the temporary surplus pushed prices on Germany's spot market on 8 May into the negative. For a brief time, the more electricity that commercial customers used, the more money they made.

Just as the introduction of negative interest rates - banks charging customers to deposit money - have prompted more questions about the state of the world's economy, so the events of 8 May have been used to throw stones at Germany's energy transition, the Energiewende.

Critics of the Energiewende blame the generous support for renewables - including a guaranteed above-market price for producers, and grid priority for wind and solar power - for such grotesque market distortions and for Germany's relatively high household electricity bills. Indeed, private consumers in the country pay more than $€ 20$ billion (US $\$ 23$ billion) in annual surcharges for the fixed feedin tariffs that go to individual producers. In response to criticism, the government last week agreed to slow the scale and pace at which Germany will further expand renewable energy over the next decade.

Electricity that is produced from renewable sources (including hydropower) has tripled in Germany over the past decade, and now provides (on most days) almost one-third of domestic electricity generation. The $19 \%$ growth in renewable-power generation last year was the largest in at least a decade. In terms of renewable-power capacity, Germany is third in the world, behind China and the United States (see Trendwatch, page 157). But at 1.1 kilowatts per capita, the 92 gigawatts that the nation produced in 2015 represents more than twice the renewable power per capita of any other large economy.

The planned amendment of Germany's renewable-energy act, agreed in principle last week, sets a $45 \%$ cap on the amount of renewable electricity generation by 2025 . And, as demanded by Brussels, future promotion of wind and solar energy will be linked to tenders, favouring producers who generate renewable power at the lowest price. Unsurprisingly, the plan has upset parts of the renewable-energy sector - in particular, smaller companies, and millions of homeowners who have
"What

Germany's case illustrates is that energy transition must be backed by comprehensive plans." invested in lucrative rooftop solar panels that fear the loss of market opportunities and revenue. Meanwhile, green lobbyists say the reforms are a concession to the fossil-fuel sector that could send a false signal to countries that regard Germany as a role model. Overall, it might seem that the Energiewende - and, by extension, renewables investment elsewhere - has failed, or is falling from political grace in troubled times.

That is wrong. Opinions will rightly differ on which fiscal and policy measures are best suited to promoting renewables. But controversies of microeconomics will not derail the grand decarbonization project that is under way.

What Germany's case does illustrate is that this transition must be backed by comprehensive energy plans. To incorporate fastgrowing, decentralized power generation into electricity grids requires improved networks, reliable tools to predict supply and demand, efficient storage and more-flexible conventional plants.

Science can help. In April, the German federal government approved a 10 -year, $€ 400$-million programme for research on the technology - smart grid technology and energy storage, for instance - that will be needed for an energy system and a market dominated by renewable sources. Funders should ensure that projects address the problems faced by suppliers and users of electricity under real-world market conditions. Sceptics may celebrate the wrinkles as renewables bed into the energy market, but the long-term trend has been set.

Of course, Germany and other countries will continue to depend on coal and gas to meet electricity demands for at least a couple of decades — but then, massive subsidies ( $\$ 500$ billion globally in 2014, against $\$ 135$ billion for renewables) mean that fossil-fuel power continues to be offered at a knock-down price. A realistic, climate-friendly energy system for the future demands greater reform of the oil and coal markets, rather than changes to the renewables sector.

\section{Second chances}

\section{The line between compliance and misconduct is finer than you might think.}

$\mathrm{T}$ here are many reasons why a research paper could be retracted, although the one that tends to dominate public discussion is research misconduct.

Similarly, there are many different definitions of research misconduct, but the one that tends to draw attention is deliberate deception and data fraud. That can help to explain why, when Nature ran a news story in January 2013 about a new course that would attempt to rehabilitate misconduct offenders, many of the online comments below the story were negative (see Nature 493, 147; 2013).

One response was typical: "If a scientist wilfully pollutes the scientific record with damaging, self-serving, purposeful lies, it is too late. If they have received funding for that fraud, I am still mystified as to why the granting agency does not seek to recoup their costs in court. Now, someone suggests we further train them on something that is obvious to any scientist with half a brain on their shoulders?"

More than three years on, the architects of the rehab course offer a progress report, which appears as a Comment article on page 173 . More than three dozen researchers have been through its doors, and, according to the authors, most leave as better scientists than when they arrived.

Attendees do not include the high-profile data fraudsters whose offences are so serious that they are fired. By definition, researchers on the course are scientists who have been caught out but whom institutions want to keep.

Most of them had seen their research privileges suspended with offences ranging from plagiarism and poor oversight to falling foul of the rules and regulations on animal welfare and informed consent. Despite the 'research misconduct' label, instances of conscious wrong-doing were rare. As one participant said: "Prior to this situation, I tried to follow the spirit of the law. Now I try to follow the letter of the law."

Two points stand out. First, the typical character and personality of these scientists, and their knowledge and attitudes, were no different from those of you and your colleagues. Misconduct, the authors say, can be down to circumstance: "we believe that most researchers may be susceptible". And second, those circumstances are becoming more common.

The most common cause of an offence was a lack of attention, prompted, among other things, by being too busy and trying to juggle too many projects. Sound like anyone you know? 